\title{
PIMECOE: A PROJECT FOR SELF-DIAGNOSIS OF THE STUDENT OUTCOME "EFFECTIVE COMMUNICATION" AND ITS IMPROVEMENT THROUGH A SELF-FORMATIVE ITINERARY
}

\author{
R. Oltra-Badenes ${ }^{1}$, E. Pérez-Esteve ${ }^{2}$, J.A. Silvestre-Cerdà ${ }^{3}$, M.C. Bas ${ }^{4}$, \\ M.J. Lerma-García ${ }^{1}$, N. Matarredona-Desantes ${ }^{5}$ \\ ${ }^{1}$ Departamento de Organización de Empresas, Universitat Politècnica de València (SPAIN) \\ ${ }^{2}$ Departamento de Tecnología de Alimentos. Universitat Politècnica de València (SPAIN) \\ ${ }^{3}$ Departamento de Sistemas de Información y Computación, Universitat Politècnica de \\ València (SPAIN) \\ ${ }^{4}$ Departamento de Matemáticas para la Economía y Empresa, Universitat de València (SPAIN) \\ ${ }^{5}$ Departamento de Composición Arquitectónica, Universitat Politècnica de València (SPAIN)
}

\begin{abstract}
Since the breakthrough of student outcomes in the university environment, "Effective Communication" is one of the most studied in Bachelor's degrees and Master's subjects. An inefficient communication can lead to misinterpretations and wrong conclusions. Therefore, it is a very important competence both in the university and in the business field. The student / graduate must know how to communicate effectively, both orally and writing, appropriately using the necessary resources and adapting to the characteristics of the situation and the audience. Despite its importance, the disparity in the domain of the competence by the students makes it difficult to work in the classroom through collective activities.

This paper presents the PIMECOE, an Innovation and Educational Improvement Project. This project aims to work on the student outcome "Effective Communication". It focuses specifically on oral communication, and to work on it, it proposes to assess the level of initial proficiency of oral communication through self-diagnosis tools. This allows the student to detect their weaknesses and strengths in the domain of the competence. Likewise, the project aims to develop a self-formative itinerary for students, which includes learning activities that improve the domain level of the competence.

In this way, first, students will have an assessment of their level of competence through a selfdiagnostic survey; and second, will have access to a series of activities that will allow him to develop the competence based on the results obtained in the self-diagnosis.
\end{abstract}

Keywords: Effective communication, oral communication, student outcomes, self-diagnosis tools, selftraining.

\section{INTRODUCTION}

In recent years, institutions of higher education have experienced various changes conditioned by the demands of today's society. The adaptation of the degree titles to the European Higher Education Area (EHEA) is one of the unavoidable factors that have led to a change in the application of teaching methodologies, and a need to adapt and make flexible the educational offer to the current reality. In particular, the inclusion of student outcomes in curricula has become very important for both the university and the business world. There is a consensus between university and business environment on the need for future employees to master certain skills for their professional development. For the student it is very important to acquire and accredit their training skills in university. On the other hand, for the employer it is very important to know the level of mastery of the competences acquired by the graduates.

Accordingly, the UPV (Universitat Politècnica de València) has included in its strategy the evaluation of two kinds of student outcomes: specific and transversal. In this way, the new undergraduate and postgraduate degrees explicitly incorporate the requirement that students must be trained in certain skills, and assessed according to the corresponding domain level of the competence.

As in [1], transversal competences are "those competencies that are key and transferable in relation to a wide variety of personal, social, academic and work contexts throughout life. In this sense, they constitute a fundamental part of the professional profile and the formative profile of all or most of the 
degrees. These are competences that include a set of cognitive and meta-cognitive abilities, instrumental and attitudinal knowledge of great value for the knowledge society".

Given that transversal competences are a complex know-how, it is necessary to determine specific learning outcomes. Therefore, it is necessary to resort to methodological strategies that favour a change of roles. A 'traditional' methodology based on lectures and problems that the teacher solves in the classroom turns out to be inappropriate under this framework. Even laboratory practices must change their approach to achieve new objectives and ensure that students acquire a set of skills that, in general, are not previously taken into account or evaluated, such as the ability to work in groups, the ability to make oral presentations, etc. [2]. To master these competences it is necessary to carry out training actions. These actions must be based on active methodologies for the learning of competences and methods of student participation that generate a deeper, meaningful and lasting learning [3].

In this context, the UPV (Universitat Politècnica de València) has identified thirteen transversal competencies that students have to develop when studying their degrees. One of UPV's transversal competencies is "effective communication", in which there is a greater consensus regarding the importance it has for future graduates. According to the institutional project developed by the UPV, it means "the ability to transmit knowledge and arguments clearly, rigorously and convincingly, both orally and in writing, using the resources properly and adapting to the characteristics of the situation and audience". It is important to differentiate the two dimensions within this competence: oral communication and writing [4].

The mastery of the competence of effective communication implies the effectiveness in the communication of ideas, knowledge and feelings through speech and writing in group activities or public presentations and speeches, among others [5]. Students who have accessed to the university have already acquired a certain amount of instrumental knowledge of techniques and strategies for a good communication, but the university must assure that further development of this competence is carried out, taking into account its important academic, professional and personal implications. From a strictly academic point of view, verbal and written interactions are the key to the teaching-learning process, since they facilitate collaborative activity, make possible the internalization of knowledge, and are fundamental to achieve a good academic performance. In professional life, it is essential to know how to transmit ideas, knowledge and feelings in a precise way to obtain greater efficiency. Finally, from a personal perspective, being able to talk in public safely and without nervousness, as well as the ease of expressing oneself in writing without difficulties, entails an increase in personal security and reinforces self-esteem [6].

It is important to bear in mind that students face the development of this competence with very different initial domain levels. This is due to the different innate abilities and different acquisition rates of this competition. In addition, this disparity can be accentuated if the students are enrolled in different degrees and cycles. Therefore, different problems arise in terms of the acquisition of this transversal competence. The following questions arise when working the "effective communication" competence:

- Which is the initial level of proficiency in this transversal competence of the students from different degrees and cycles?

- How is this competence worked in class?

- What evaluation / diagnostic tools are used to analyse the proficiency level of the competence?

- There exist support and improvement tools that guide the student to the acquisition / improvement of the competence?

- What training activities should be proposed to improve the mastery level of the competence?

The PIMECOE project aims to give an answer for all these questions. This paper presents the teaching innovation project that aims to establish a series of tools that students can use in order to improve their mastery level in the transversal competence "effective communication", focusing on the oral communication part. To do this, some objectives and a project plan are proposed to achieve them, consisting of a series of tasks that are presented in the following section. 


\section{METHODOLOGY}

In this section we describe how the project and its estimated work plan will be approached, establishing its objectives, tasks and estimated calendar, as well as the participating entities and resources.

\subsection{Objectives}

The main purpose of the project is to create and provide students with a self-diagnostic tool that allows them to know their proficiency level of the transversal competence "effective oral communication" before starting the subject, and to propose them, based on the result obtained in the self-diagnosis, an auto-formative itinerary composed of different training activities with the final objective of developing the transversal competence at the appropriate level of proficiency.

This final objective will be achieved through the achievement of six specific objectives, which are the following:

- Objective 1. To investigate the availability of technological and assessment tools available for teachers to evaluate the "effective communication" competence and the training activities that exist to work on it.

- Objective 2. To elaborate a self-diagnostic guide of the initial mastery level of the competence.

- Objective 3. To develop an auto-formative itinerary for the improvement of the competence according to the initial level of proficiency and the level of proficiency that students should reach at the end of the subject. This itinerary will be developed through the design of training activities for the continuous improvement of the evaluated competence.

- Objective 4. To introduce the self-diagnostic tool and the self-formative itinerary in the teaching-learning methodology of those subjects of different degrees and cycles that deal with the competence.

- Objective 5. To improve the self-diagnosis guide and the self-formative itinerary based on the perceptions of the students through the use of an opinion survey.

- Objective 6. Identify good practices, recommendations and areas of improvement of interest for teachers to work on this competence in classroom.

\subsection{Project Plan}

The tasks to be developed for each of the proposed objectives are described below.

Tasks related to objective 1:

- Task 1.1. Review of the available technological tools and evaluation instruments for the assessment of the "effective communication" competence.

- Task 1.2. Review of the existing training activities in the bibliography to work on the competence.

Tasks related to objective 2 :

- Task 2.1. Identification and classification of basic and advanced indicators that define each mastery levels of the competence.

- Task 2.2. Formulation of descriptors that help students to be placed in three mastery levels (no mastery, medium mastery, high mastery) with respect to each of the basic and advanced indicators that define the competence.

- Task 2.3. Drafting of the self-diagnosis guide of the initial mastery level of the competence including all the descriptors defined in task 2.2.

Tasks related to objective 3:

- Task 3.1. Definition of individual training activities that contribute to the improvement of each basic indicator of the mastery level of the competence.

- Task 3.2. Definition of group activities that contribute to the improvement of each basic indicator of the mastery level of the competence, and the role that the student must assume in them according to the capacity that the student wishes to achieve. 
- Task 3.3. Preparation of the document "Self-formative itinerary for the improvement of the transversal competence 'effective oral communication'".

- Task 3.4. Drafting of the document "learning framework contract" where students must agree with the teacher what, how and when they will carry out the activities included in the document "self-formative itinerary" in order to improve their mastery level of the competence.

Tasks related to objective 4 :

- Task 4.1. Presentation and use of the tools during the first week of the course.

- Task 4.2. Drafting of learning contracts by students.

- Task 4.3. Follow-up of the students' work by the teachers.

Tasks related to objective 5 :

- Task 5.1. Design of a student opinion survey in order to collect information about:

- perception of the effectiveness of the self-diagnostic tool proposed to assess their initial mastery level,

- perception of the effectiveness of the self-formative itinerary,

- perception of the improvement of the mastery level of the competence during the subject,

- perception of the improvement of the mastery level of the competence at the end of the subject.

- Task 5.2. Run the survey to the students participating in the program.

- Task 5.3. Analysis of the results.

- Task 5.4. Reformulation / improvement of the self-diagnostic guide, the self-formative itinerary and the learning contract based on the results obtained.

Tasks related to objective 6:

- Task 6.1. Preparation of a report of good practices and recommendations to work on this competence in classroom according to the results obtained in this project.

Figure 1 shows the scheduled PIMECOE project's work plan. The project finishes on January 2018, with the end of tasks 5.4 and 6.1 , coinciding with the end of the teaching period of the subjects under study.

\begin{tabular}{|c|c|c|c|c|c|c|c|c|c|c|}
\hline & $\begin{array}{c}\text { SEP } \\
17\end{array}$ & $\begin{array}{c}\text { OCT } \\
17\end{array}$ & $\begin{array}{c}\text { NOV } \\
17\end{array}$ & $\begin{array}{c}\text { DEC } \\
17\end{array}$ & $\begin{array}{c}\text { JAN } \\
18\end{array}$ & $\begin{array}{c}\text { FEB } \\
18\end{array}$ & $\begin{array}{c}\text { MAR } \\
18\end{array}$ & $\begin{array}{c}\text { APR } \\
18\end{array}$ & $\begin{array}{c}\text { MAY } \\
18\end{array}$ & $\begin{array}{c}\text { JUN } \\
18\end{array}$ \\
\hline T 1.1 & & & & & & & & & & \\
\hline T 1.2 & & & & & & & & & & \\
\hline T 2.1 & & & & & & & & & & \\
\hline T 2.2 & & & & & & & & & & \\
\hline T 2.3 & & & & & & & & & & \\
\hline T 3.1 & & & & & & & & & & \\
\hline T 3.2 & & & & & & & & & & \\
\hline T 3.3 & & & & & & & & & & \\
\hline T 3.4 & & & & & & & & & & \\
\hline T 4.1 & & & & & & & & & & \\
\hline T 4.2 & & & & & & & & & & \\
\hline T 4.3 & & & & & & & & & & \\
\hline T 5.1 & & & & & & & & & & \\
\hline T 5.2 & & & & & & & & & \\
\hline T 5.3 & & & & & & & & & & \\
\hline T 5.4 & & & & & & & & & \\
\hline T 6.1 & & & & & & & & & & \\
\hline
\end{tabular}

Figure 1. Scheduled PIMECOE project's work plan. 


\subsubsection{Participant Entities}

The PIMECOE Project is being developed with the participation of 4 entities, being all of them UPV's schools. Concretely, these are the School of Civil Engineering, School of Architecture, School of Industrial Engineering and the School of Agricultural Engineering and Environment. The project is run in five different degrees, being two of them Master degrees, and Bachelor degrees the remaining three.

The participating degrees and entities are shown in Table 1.

Table 1. Degrees and entities participating in the PIMECOE project.

\begin{tabular}{l|l}
\hline \multicolumn{1}{c|}{ Degree } & \multicolumn{1}{c}{ Entity (School) } \\
\hline Master's Degree in Planning and Management in Civil Engineering & School of Civil Engineering \\
\hline Master's Degree in Preservation of Architectural Heritage & School of Architecture \\
\hline Bachelor's Degree in Industrial Organization Engineering & School of Industrial Engineering \\
\hline Bachelor's Degree in the Fundamentals of Architecture & School of Architecture \\
\hline Bachelor's Degree in Agricultural and Biological Engineering & $\begin{array}{l}\text { School of Agricultural Engineering } \\
\text { and Environment }\end{array}$ \\
\hline
\end{tabular}

\section{RESULTS}

Regarding the results of the project, we expect to generate a set of tools, documents, evidences, advices and best practices that can help to develop the transversal competence "effective oral communication" and that can be shared and used by the whole academic community. More precisely, the outcomes of the project, given by each project's objectives, are the following:

- Objective 1.

- Document "Assessment tools and formative activities to develop the transversal competence 'effective oral communication'".

- Objective 2 .

- Document "Self-diagnosis guide to determine the initial mastery level of the transversal competence 'effective oral communication'". This document will be publicly released and available for the whole academic community.

- Objective 3.

- Document "Self-formative itinerary for the improvement of the transversal competence 'effective oral communication' based on the initial mastery level and the proficiency level that should be reached at the end of the subject". This document will be publicly released and available for the whole academic community.

- Document "Framework learning contract". This document will be publicly released and available for the whole academic community

- Objective 4.

- Tracking documents used by teachers.

- Objective 5.

- Surveys completed by students.

- Document "Proposals to improve the self-diagnosis guide and the self-formative itinerary".

- Objective 6.

- A minimum of five recommendations and good practices to work effectively the competence in the classroom. 


\section{CONCLUSIONS}

University subjects must work and develop at the same time subject-specific competences and transversal competences through proper activities carefully designed to do it. This would facilitate a lot the learning process of both types of competences at the same time. However, the reality is that due to the reduced duration of the courses and the extensive curricula they cover, teachers usually prioritize the work on specific competences to the detriment of transversal ones. As a result of this, in many subjects there is no curricular alignment since transversal competences are evaluated without having them been worked in classroom, or, provided they have been worked, no training activities have been carried out to specifically improve the mastery level on them. That is why this project focuses on the mastery level of a particular transversal competence and how it can be worked in the classroom by the students.

In this paper, we have presented an overview of the PIMECOE project. The project is centered in the transversal competence "effective oral communication", and its main objective is to create and provide students with a self-diagnostic tool that allows them to know their mastery level of the aforementioned competence, followed by an auto-formative itinerary composed of different training activities adapted to the result obtained in the self-diagnosis tool, with the final objective of developing the transversal competence at the appropriate mastery level. We have also presented the objectives, tasks, and the scheduled work plan. At the time of writing, the project is still being developed, and the presented activities and tasks are being carried out too. The project is being implemented in some of the planned subjects, and, soon, results from the firts steps of the project will be published. The results and the feedback obtained so far are quite promising, so that we expect to confirm this trend at the end of the project.

\section{ACKNOWLEDGEMENTS}

This work has been developed within the research project called "Autodiagnóstico del nivel de dominio inicial de la competencia transversal "Comunicación Efectiva" y su mejora a través de un itinerario autoformativo" (Ref.: PIME/2017/B/025-14) funded by the Vice-Rectorate for Studies, Quality and Acreditation at Universitat Politècnica de València

\section{REFERENCES}

[1] ICE - Instituto de Ciencias de la Educación. Universitat Politècnica de València (2015). Proyecto Competencias Transversales UPV. <http://www.upv.es/entidades/ICE/info/U0724624.pdf> [Consulta: 27 de diciembre de 2017].

[2] Oltra-Badenes, R. y Gil-Gómez, H. (2015). "Técnicas de aprendizaje cooperativo: aplicación de metodologías activas en la asignatura de Recursos Humanos en Empresas Industriales". En: 3rd International Conference on Innovation, Documentation and Teaching Technologies (INNODOCT/15). Open Innovation and Coolhunting in Education. 374-382.

[3] A. Fernández. (2006). "Metodologías activas para la formación en competencias". Educatio Siglo XXI, 24. pp 35-56.

[4] Universitat Politècnica de València (2012). Competencias transversales. Blog <http://www.upv.es/contenidos/COMPTRAN/info/956832normalc.html> . [Consulta: 23 de diciembre de 2017].

[5] A. Villa, A., M. Poblete. (2007). "Aprendizaje Basado en Competencias. Una propuesta para la evaluación de las competencias genéricas". Universidad de Deusto, Bilbao.

[6] R. Sayós. (2013). "Las competencias transversales en las titulaciones de grado de la Universidad de Barcelona. Orientaciones para su desarrollo". Cuadernos de Docencia Universitaria, 27. 